\title{
Implementation of the Children's Pattern in Family Based on Cultural Success in Medan City
}

\author{
Peny Husna Handayani ${ }^{1}$, Apiek Gandamana ${ }^{2}$, Farihah ${ }^{3}$ \\ \{peny_husna@unimed.ac.id ${ }^{1}$, apiek_gandamana@unimed.ac.id ${ }^{2}$ \} \\ Department of Universitas Negeri Medan, Indonesia ${ }^{1,2,3}$
}

\begin{abstract}
The purpose of this study is to describe the implementation of parenting type in the family of Batak, Minang, Malay, Javanese, Acehnese, and Nias in Medan. Patterns to be analysed are authoritarian, democratic, and permissive parenting. This analysis will provide an overview of the application of the type of parenting in the family based on ethic culture that lies behind the family. The sample in this study are families from the tribes of Batak, Minang, Malay, Javanese, Aceh, and Nias which is live in the city of Medan. This study used descriptive method. The result showed that the average family of Batak, Minang Malay, Javanese, Aceh, and Nias in Medan applied 46\% authoritarian parenting, democratic $83 \%$, and $35 \%$ permissiveness.
\end{abstract}

Keywords: parenting, family, culture, ethnic

\section{Introduction}

Parenting is a trip with a long-term goal carried out by parents towards their children in the family. Family is the environment that children first recognize and become the first and foremost environment in child development (Handayani, 2017). The pattern of interaction between parents and children, such as how to apply the rules, teach values / norms, give attention and love and show good attitudes and behaviors so that they are used as role models for their children is called parenting (Theresia, 2009).

According to Baumrind (in Santrock, 2010), parenting is in principle a parental control. The same thing was stated by Kohn (1971) who stated that parenting is the way parents interact with their children including; giving rules, prizes, penalties, and giving attention, as well as responses to children's behavior.

Parenting is a way, form or strategy in family education carried out by parents to their children. The strategies, ways and forms of education carried out by parents to their children are certainly based on the expectations of parents. It is hoped that the education provided by parents makes children able to survive according to their nature and environment by growing the potential in the form of inner strength, mind and physical strength in each child. (Anto, et al. 1998). The parenting style given by parents to their children also determines social behavior and the level of intelligence of children. Parenting is influenced by the parenting style they get first when they are still children. Past care will affect discipline patterns, conflict resolution, or even life goals (Shihab, 2017). Parenting has a long journey in the process.

Every family has a style of caring for their children. Parenting is influenced by the age of parents, the involvement of parental members such as extended parents, parents' education, 
husband and wife harmony, and prior care experience. Dayakisni and Yuniardi (2012) stated that culture is also one of the factors that influence parenting parents towards their children.

One city with a multiethnic population is Medan. Medan is the capital of North Sumatra Province, Indonesia. The city is the third largest city in Indonesia after Jakarta and Surabaya, as well as the largest city in Java. Medan city is the gateway to the western part of Indonesia. Bordering the Straits of Melaka makes Medan a city of trade, industry and business that is very important in Indonesia. In 1632, Medan was used as the center of the government of the Deli Sultanate, a Malay kingdom until the Europeans arrived, and the Dutch East Indies gave the status of the city and made it the center of the residency of East Sumatra. Entering the 20th century, Medan became an important city outside Java. Therefore, no wonder, today Medan is a multiethnic city where the population consists of people with different cultural and religious backgrounds.

Besides Malays and Karo as early inhabitants, Medan is dominated by ethnic Batak, Javanese, Minang, Chinese, Mandailing, Nias, Aceh, Indian and other ethnic groups. These cultural tribes have their own characteristics and cultural values that are inherited by their ancestors and influence the parenting style of their children. Because culture is one of the factors that influence children's parenting in the family. Therefore, it is interesting to observe how the implementation of childcare patterns in families with Batak, Mandailing, Karo, Nias, Malay, Minang, Javanese and Acehnese cultural backgrounds who live in Medan City.

\section{Methodology}

This study uses descriptive method with a qualitative approach. Descriptive research is directed to provide symptoms and facts or events systematically and accurately (Rianto, 1996). Research with descriptive methods can reveal the situation as it is (Handayani, 2016). The qualitative approach makes it easy for researchers to uncover the things that are the purpose of this research (Gandamana, 2015). Data can be collected through observation, interview, documentation, or technical combination techniques (Sugiyono, 2010: 309). Descriptive method is used to obtain an empirical description of the application of childcare patterns in families with grassroots backgrounds of Batak, Nias, Malay, Minang, Javanese, and Sundanese cultures, which are in the city of Medan.

The population in the study were all families with various ethnic groups / cultures in the city of Medan. The sample in this study were families with Batak, Nias, Minang, Malay, Javanese, and Acehnese cultural backgrounds, each family represented by a minimum of 5 families, who had settled in the city of Medan.

During the study the data was collected through several data collection techniques which consisted of filling out questionnaires about parenting, interviews with parents, and documentation. Important factual events that occur during the study will be recorded in full through the researchers' field notes. Data analysis was carried out qualitatively and used descriptive statistics. The questionnaire that will be used in this study is processed by quantitative analysis, namely by using the formula: If the statement is negative, then often (0), sometimes (1), never (2). If a positive statement, then often (2), sometimes (1), never (0). The results of the percentage of quantitative calculations are interpreted using the rule in table below. 
Table 1. Categorization of Percentage Results

\begin{tabular}{|c|c|}
\hline Persentage & Categorization \\
\hline $0 \%$ & None \\
\hline $1 \%-30 \%$ & In part \\
\hline $31 \%-49 \%$ & Almost half \\
\hline $50 \%$ & Hald of it \\
\hline $51 \%-80 \%$ & Most of the \\
\hline $81 \%-99 \%$ & Almost entirely \\
\hline $100 \%$ & All of it \\
\hline
\end{tabular}

\section{Results And Discussion}

Every family has their own parenting style. They have a way to educate their children, one of which may be influenced by the cultural background of their parents. Medan, which is the largest metropolitan city on the island of Sumatra, has a very heterogeneous population. In this city, family lives from various cultural backgrounds. We distributed questionnaires to children from 8 different family cultural backgrounds, namely from families with Batak, Nias, Karo, Mandailing, Minang, Malay, Javanese, and Acehnese cultural backgrounds. The eight cultural backgrounds of this family have the same tendency in the style of educating their children, which tends to use democratic-authoritarian parenting. The results showed that the average family with a Batak, Nias, Karo, Mandailing, Minang, Malay, Javanese, and Acehnese culture in the city of Medan applied 46\% authoritarian parenting, 83\% democratic, and $35 \%$ permissive. The copyright form is located on the authors' reserved area.

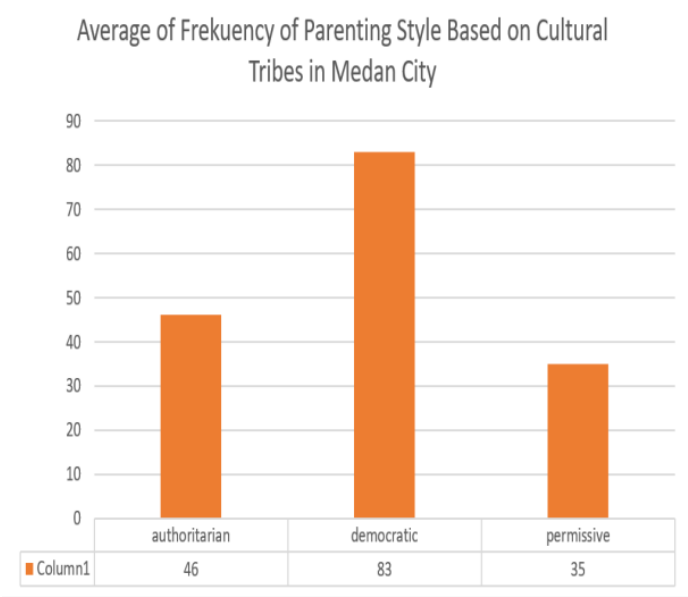

Fig. 1. The bar chart of an average trend of parenting in cultured families in Medan City

Based on the diagram above, we can see that families with Batak, Nias, Karo, Mandailing, Minang, Malay, Javanese and Acehnese cultural backgrounds in the city of Medan, almost all or $83 \%$ tended to educate and care for their children using patterns democratic foster care. As many as $46 \%$ or almost half tend to educate and care for their children using authoritarian 
parenting, and as many as $35 \%$ or a small proportion tend to educate and care for their children using permissive parenting.

Figure 2 below will show a parenting pattern of each family with a cultural background of Batak, Nias, Karo, Mandailing, Minang, Malay, Javanese and Acehnese in the city of Medan.

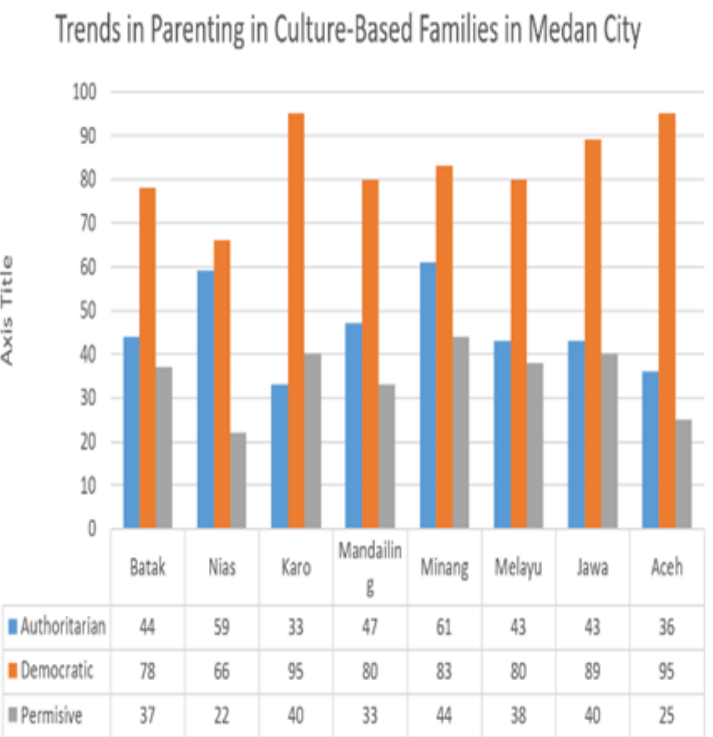

Fig. 2. The bar chart of parenting trends in family based culture in Medan City

Based on the diagram above, we can know that all cultural tribes that researchers observe, have the same tendency, namely the democratic type of parenting becomes the most widely used parenting style, then authoritarian, and what few families use is permissive parenting. Families with Acehnese and Karo ethnic backgrounds are the most likely to use democratic parenting, which is $95 \%$ or almost entirely. But if we observe the number of incompetence for authoritarian and permissive parenting, families with ethnic backgrounds in Aceh, are more likely to use authoritarian parenting than permissiveness. The diagram shows the tendency of authoritarian parenting is greater than permissive parenting, namely authoritarian parenting $36 \%$, while permissive parenting $25 \%$. Therefore, we can say that families with ethnic cultural backgrounds in Aceh tend to have democratic-authoritarian parenting. The results of the research questionnaire showed that families with Batak, Mandailing, Nias, Minang, Malay and Javanese ethnic backgrounds had the same tendency as the families of this Aceh cultural background, which tended to have democratic-authoritarian parenting.

It's different from families with Karo cultural background. Only families with ethnic backgrounds have democratic-permissive parenting. The tendency of permissive parenting is greater than the trend of authoritarian parenting, namely the tendency of permissive parenting by $40 \%$, while the tendency of permissive parenting is $33 \%$. 


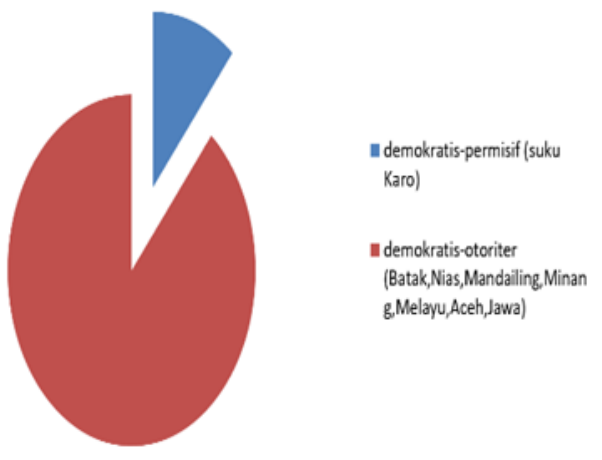

Fig. 3. Diagram of parenting tendency in family.

Baumrind (in Santrock, 2010) states that parenting is all forms and processes of interaction that occur between parents and children in the form of certain parenting in the family that will influence the child's personality development. Baumrind divides parenting into three styles of parenting, namely democratic, authoritarian, and permissive parenting.

Parents with democratic parenting will prioritize the interests of children, but do not hesitate in controlling children. Parents are also open, flexible, and provide opportunities for their children to grow and develop with rational rules, so parents have a close relationship with their children, they will invite their children to get involved in making rules and implementing rules with full awareness (Santrock, 2010).

Parents with authoritarian parenting tend to set an absolute standard that must be obeyed. Not infrequently followed by threats. This type of parent knows no compromise in communicating, so usually one-way communication occurs. Parents with permissive parenting lack the demands or control of their children (Santrock, 2010).

In fact, in society, not $100 \%$ of parents use only democratic, authoritarian, or permissive parenting. Based on the results of the questionnaire and shown in Figures 2 and 3, it can be seen that parents, especially with the background of Batak, Mandailing, Karo, Nias, Malay, Minang, Aceh and Javanese ethnic backgrounds, have a tendency to combine parenting in educating their children. In this case, researchers classify into two, namely democraticauthoritarian, and democratic permissive. The point is that democratic-authoritarian parents are more democratically dominant, but under certain conditions there will be authoritarian parenting. Likewise democratic-permissive parenting, meaning dominant democratic parents, but under certain conditions, permissive parenting will emerge.

Ahmad (2012) stated that the culture of parent's origin influences parenting to their children, even though the environment does not originate from the environment, but sometimes other languages and parenting are still used from their original culture. A child in the family will be nurtured according to the cultural values that are believed by both parents (Rahayu and Amanah, 2010). Parenting among Sumatran cultures that are applied using democratic and permissive parenting, parents give more freedom to children in determining choices so that children become more free in determining their attitude. Parents are not fixated on the cultural values that exist in educating children, the most important is the attitude of parents as a figure in guiding and educating children. As for the Javanese children parenting is applied not according to their own will or will, but always adheres to Javanese cultural values 
and traditions. Parenting style in Javanese culture is more dominant in authoritarian parenting and power assertion, parents have a dominant role in educating children and determining children's desires, parents also limit children's behavior so that children's behavior does not go beyond the limits of Javanese cultural values that are highly upheld high by the community. As a result, children become stiff and can not be free to express because all children's behavior is limited by the existing culture.

Based on this research, families with Batak, Mandailing, Karo, Malay, Minang, Nias, Aceh, and Javanese ethnic backgrounds show a dominant tendency to use democratic parenting, even in certain conditions in the Batak, Mandailing, Malay cultural backgrounds. , Minang, Nias, Aceh and Java, authoritarian parenting emerged. As for families with Karo backgrounds, permissive parenting appears. This is due, in addition to the ancestral cultural factors, also because of the level of parental education, previous parenting experiences, and the challenges of the times.

\section{Conclusions}

Families with Batak, Mandailing, Karo, Nias, Malay, Minang and Javanese backgrounds living in Medan, on average applied $46 \%$ authoritarian parenting, $83 \%$ democratic, and $35 \%$ permissive. Based on the results of the study, families with a cultural background in Aceh and Karo showed the greatest tendency of adopting democratic parenting by $95 \%$ or almost entirely. The data also shows that there is a combination of parenting practices in the family. For families with Batak, Nias, Mandailing, Malay, Aceh and Javanese cultural backgrounds, they adopt parenting that tends to be democratic-authoritarian. Meanwhile, for families with grassroots background in Karo culture, they show a tendency for democratic-permissive parenting. This is influenced by the level of education of parents, the age of parents, experience in previous care, challenges of the times, and the culture of their ancestors.

ACKNOWLEDGEMENTS. We would like to gratefully acknowledge funding from Lembaga Penelitian Universitas Negeri Medan.

\section{References}

[1] Ahmad.: Pola Asuh Orang Tua dalam Budaya Jawa dan Sumatera (2012)

[2] Dayakisni, T., Yuniardi, S.: Psikologi Lintas Budaya,Malang (2012)

[3] Gandamana, A.: UMM Press.

Gandamana, A., 2015. Persepsi Masyarakat kecamatan Warung kondang terhadap Perpolisian Masyarakat (Community Policing) di Polsek Warung kondang dalam Wilayah Hukum Polres Cianjur. Vol. 4, pp. 136-145. Jurnal Handayani (2015)

[4] Gertz, H.: Aneka Budaya dan Komunitas di Indonesia (1963)

[5] Handayani, P.H.: Pemanfaatan jejaring Facebook dalam Peer Assessment Online untuk Menilai Sikap Ilmiah Siswa. Vol. 2, pp. 71-80. Jurnal Penelitian dan Pembelajaran IPA (JPPI) (2016)

[6] Handayani, P.H.: Pengembangan Kreativitas Anak Usia Dini dalam Keluarga. Vol. 15, pp. 46-56. Jurnal Keluarga Sehat Sejahtera (2017)

[7] Hendar, dkk.: Multikulturalisme Belajar Hidup Bersama dalam Perbedaan (2009)

[8] Rahayu, M.D., Amanah, S.: Factor-Faktor yang Berhubungan dengan Pola Asuh Anak pada Keluarga Etnis Minang, Jawa, dan Batak. Vol.6. Jurnal Penyuluhan (2010) 
[9] Sari, D.A.: Pola Pengasuhan pada Suku Batak (2017)

[10] Santrock, J.W.: Life-span Development 13thed (2017)

[11] Shihab, N.: Keluarga Kita Mencintai dengan Lebih Baik (2017)

[12] Suparyanto.: Konsep Pola Asuh Anak (2010)

[13] Tinambunan, D.: Orang Batak Kasar? (2010)

[14] Vergouwen, J.: Masyarakat dan Hukum Adat Batak Toba (2004) 